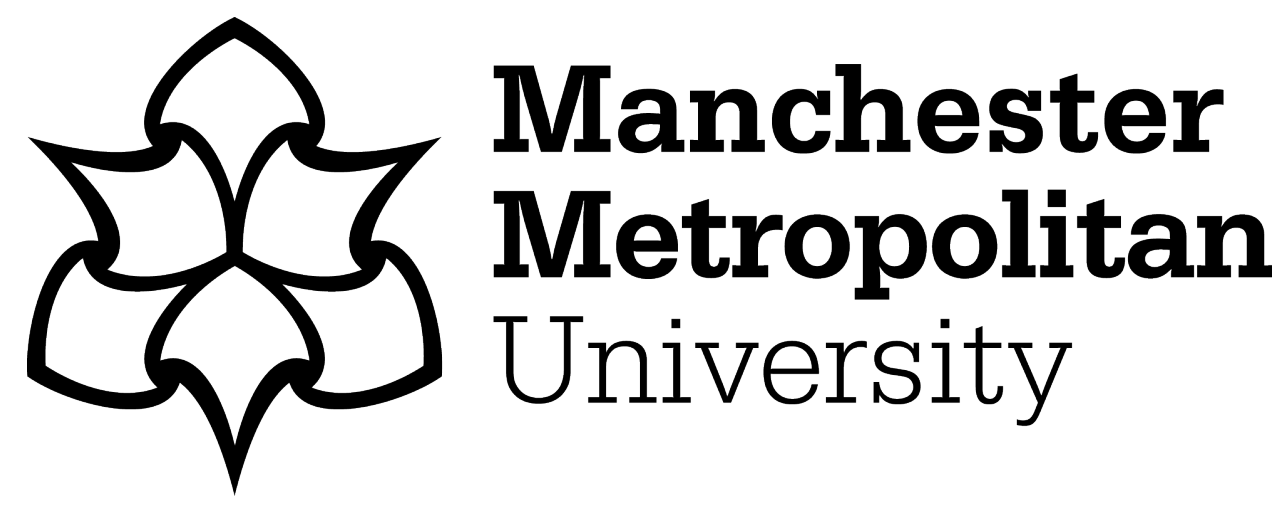

Rachel Nolan (2018) Uplift, Radicalism, and Performance: Angelina Weld Grimké's Rachel at the Myrtilla Miner Normal School. Legacy, 35 (1). p. 1. ISSN 0748-4321

Downloaded from: https://e-space.mmu.ac.uk/629071/

Version: Accepted Version

Publisher: Project Muse

DOI: https://doi.org/10.5250/legacy.35.1.0001

Please cite the published version 


\title{
Uplift, Radicalism, and Performance: Angelina Weld Grimkés Rachel at the Myrtilla Miner Normal School
}

\author{
RACHEL NOLAN \\ University of Connecticut
}

$\mathrm{I}_{\mathrm{s}}^{\mathrm{n}}$

n the summer of 1883, the African American schoolteacher Lucy Ella Moten ${ }^{1}$

sought an appointment as principal of the Myrtilla Miner Normal School for Colored Girls in Washington, DC. ${ }^{2}$ Despite her multiple professional degrees and her service as a teacher in the city's public schools for several years, the board of education initially challenged her fitness for the position, claiming that Moten failed to conform to the standards of respectability necessary for such a post. Citing her gregarious lifestyle-a fondness for male company, theater, and cards-the board asserted that Moten was "far too fascinating for so responsible a position" (Corrothers 103). The would-be principal was ultimately invited to assume her post at the Miner teacher-training institution after the board's chair, Frederick Douglass, intervened on her behalf. Douglass persuaded the board to accept Moten's application on condition that she reform her behavior, and a compromise was struck. ${ }^{3}$ If board members were initially concerned about her commitment to respectability, their concerns could not have lasted long. Moten's tenure at the Miner School lasted almost four decades. Over the course of her long career, Moten instituted a rigorous program of intellectual and moral improvement, and became renowned for her "puritanic self-discipline" (Corrothers 104). And yet, she also called attention to the interdependency of professional and community interests. Educational ideals, Moten insisted, must be "born from ... experience gained by coming into actual touch with living problems" (L. E. Moten, "Report” 317). Black women's literary contributions played a role in the principal's-and by extension the Miner School's-socially engaged educational credo.

This essay spotlights the relationship between the Miner School's complicated racial uplift mission and black women's protest literature. In March 
1916 the school hosted the inaugural performance of the first black-authored anti-lynching play, Angelina Weld Grimkés Rachel. Sponsored by the National Association of Colored People (NAACP) and billed as the first attempt to use the stage to protest racist violence, the play explores the impact of lynching on black families from the perspective of black women. The plot centers on Mrs. Loving and her two grown children, Rachel and Tom, who are trying to get by in a northern American city and a society that treats black people with, as Tom puts it, "a pretense of liberality" (49). The family initially bears the hardships of racial discrimination with fortitude. While Tom seeks employment as an electrical engineer, Rachel spends her days happily daydreaming about her future life as wife and mother, a prospect on the near horizon. She indulges this desire by taking into her care a young neighborhood boy, Jimmy. But Mrs. Loving's revelation that Rachel and Tom's father and brother were victims of a southern lynch mob has a traumatic effect. Rachel spirals into a state of madness and, at the play's denouement, proclaims that it is "a kindness-sometimes-to kill" black children rather than expose them to the world's cruelty (88). This dramatic conclusion has proven perplexing for early audiences and contemporary readers alike. Indeed, it would have been particularly striking to an audience of trainee teachers at the Miner School who would soon find themselves responsible for the well-being and education of many of the city's black children.

This essay examines Grimkés play in relation to the Miner School and the professional-educational discourses circulating in Washington, DC, communities at the time of its initial production. Between 1890 and 1910, as Evelyn Brooks Higginbotham notes, the number of black women in the professions increased by over 200 percent (41). In these decades, women came to represent 43 percent of all black professionals, a statistic attributable to women's gains in the field of education (Higginbotham 41). Moten emblematizes this transformation. Like other prominent black women educators-such as Mary Church Terrell and Anna Julia Cooper-Moten strove to establish and maintain a position within this class of educated and upwardly mobile black women. The terms of their inclusion, as indicated above, demanded conformity to what Higginbotham terms a "politics of respectability" (14). Practices of respectability contested racist tropes of black hypersexuality and debased motherhood even while shoring up bourgeois and patriarchal assumptions about women's ideal, reproductive role in society.

Although literary scholars have noted that Rachel was initially staged at the Miner School, the relationship between the politics of the play and the politics of the women who staffed and administered the institution at the time has yet to be established. Recuperating this relationship is constructive on two counts. 
First, it provides new context for understanding the play's graphic rejection of racist and patriarchal violence. Second, addressing this relationship reveals that radical expressions of black female desire may have shaped and even sustained the professional ambitions of women such as Moten and the prospective teachers under her tutelage. I contend that the Miner School performance of Rachel offers an occasion for continued debate about the nature of black women's relationship with respectability.

My analysis redirects the substantial body of scholarship dealing with the play. Black theater and literary scholars such as Akasha (Gloria T.) Hull, Judith Stephens, Kathy Perkins, Angeletta K. M. Gourdine, and Koritha Mitchell all address Rachel's contribution to twentieth-century feminist social activism. These scholars agree that Grimkés play exposes the impact of terror on black women and children and, in doing so, enables a more expansive and nuanced view of struggles for racial equality and justice in the United States. These critics also build a case for reading Rachel as a vehicle for feminist interracial dialogue and cooperation. The latter thesis is substantiated by the fact that Grimké explained in her letters that she wrote the play in order to appeal to white women. "[I]f I could reach their hearts," she writes, "then perhaps instead of being active or passive enemies they might become, at least, less inimical and possibly friendly" (qtd. in Tate 219). I suggest, however, that refocusing discussion on the context of Rachel's initial staging provides new insight into how the play may have also nourished the commitments at the heart of black women's institutional work and social politics in the early twentieth century. To this end, I draw from and extend Claudia Tate's early reception history, which situates the play directly in relation to discourses of black women's political agency, literary activism, and reform work.

Specifically, I augment and complicate Tate's thesis that Rachel constitutes a rejection of domestic ideals and the wider uplift ideology that such ideals supported. By recuperating the play's inaugural performance, I demonstrate how protest against the limits of a psychically restrictive uplift ideology was incorporated into and constitutive of uplift itself. The teachers at the Miner School maintained professional credibility by adhering to a very specific code of conduct that one teacher referred to as "the art of living" (Jenifer 281). Moten's immediate goal was to foster moral consciousness and self-respect among prospective teachers, but her long-term objective was to position black women teachers as domestic stewards, promoters and protectors of the black nuclear family and, by extension, the race itself. Grimkés play ostensibly expresses a repudiation of such goals. Through its central representation of infanticide and racial abjection, Rachel contests the respectability and maternalism that struc- 
tured the lives of the Miner School teachers. Nonetheless, Moten invited the play into the school, and Rachel's critique became part of the school's horizon of possibility.

In tracking the relationship between Rachel's protest aesthetic and the forms of agency available to the Miner School teachers, I first turn to textual analysis of the play itself. I examine Rachel's renegotiation of domestic and maternalist discourses and, subsequently, the play's critique of class conflict within African American communities. I then situate my reading of the play in relation to a recovered history of the Miner School. I examine Grimkés work in relation to primary documents related to the school and to the play's inaugural production-institutional histories, reports of the board of education, and performance programs. My analysis throughout is shaped by methodological concerns that incorporate two separate but overlapping critical frameworks: the history of black respectability and black performance. Such concerns are continuous with recent scholarly efforts to re-map respectability. Brittney Cooper, for instance, complicates foundational accounts of respectability in order to recuperate black women's intellectual innovations (23). My reassessment of text and context positions the Miner School professionals squarely within a genealogy of black feminist critical thought.

These aspirational women pursued social and economic mobility by donning the trappings of bourgeois society, but they also engaged directly with a highly critical aesthetic project that exposed the material limitations of the maternal-professional ideology and praxis of which they were a part. Recovering their ambivalent relation to respectability cautions against taking at face value an ideology of uplift that played out in a complex set of historical practices. The Myrtilla Miner Normal School, though committed to uplift, was a materially precarious site. I argue that the performance of Grimkés Rachel at the school may have stimulated self-reflection among black women professionals actively engaged in shaping_and reshaping_discourses of freedom.

\section{READING DOMESTICITY AND CLASS CONFLICT IN RACHEL}

What does it mean that the Miner School teachers, professional women invested in the project of racial uplift, invited into their institution a play that asked whether it might not be better to simply murder black children? In the final act, Rachel gives voice to this question. Speaking to her would-be fiancé, John Strong, she asks: "Don't you believe-it-a-a-kindness-sometimes-to kill?" (88). Tate reads this question as evidence of black women's chronic despair in the early decades of the new century, writing that Rachel's nihilism "dramatize[s] the destruction" of black women's "sexual, racial, and professional 
desires" (222). For Tate, one of the first scholars to examine Grimké's work in its historical context, Rachel's refusal of the bourgeois family ideal is consistent with the growing sense of apprehension among African Americans in the first decade of the twentieth century. During these years, as the promise of earlier Reconstruction-era policies faded, African Americans confronted a new context of discrimination characterized by employment restrictions, political disenfranchisement, and extralegal violence. In the face of obstacles to personal and collective well-being, earlier certainties about the viability of the bourgeois family as a vehicle for racial equality gave way to doubt. In contrast to the latenineteenth-century domestic fiction that venerated black family formation as the apogee of racial progress and aimed to "gratify" the expectations of the hopeful African American middle classes, Grimkés body of work registers a very different set of experiences and expectations (96). Rachel, in Tate's words, "exploit[s] the domestic discourse to chronicle ... the deterioration of black Americans' collective dream of freedom as full U.S. citizens" (214). In Tate's view, Rachel's "nullification" and "repudiation" of conventional conjugal and maternal discourses reflects and expresses a more widespread sense of unease with the emerging social order (16).

Tate's analysis rightly calls attention to the sheer scale of black disenfranchisement at this time, but examining the play in the context of the Miner School invites consideration of how, and to what extent, this staging of despair promoted, complemented, or complicated black women's institution-building efforts. Before considering how Rachel may have resonated with or undermined the expectations of its first audience, it is constructive to assess how the play itself articulates a protest ethos. In this section I revisit the history of racial uplift in order to track Rachel's critique of bourgeois domesticity, professionalism, and widening intraracial class disparity.

Tracking the play's engagement with maternal violence and class conflict calls for particular consideration of black women's relationship with middleclass respectability projects. In his foundational study of uplift ideology, Kevin Gaines traces what he calls the "contradictory" logic of uplift and the ambiguous social position of the black middle classes (xiii). On the one hand, uplift purported to incorporate the struggles of all black Americans and, in this sense, represented a continuation of the broadly inclusive Reconstruction-era liberation discourses. At the same time, the class assumptions of many proponents of uplift shored up, in Gaines's words, a "moral economy of class privilege, distinction, and even domination within the race" (17). For black women, securing a position within this economy involved capitulation to black patriarchal leadership and, more often than not, falling in line with patriarchal family ideals. "Claiming respectability," in short, "meant denouncing nonconformity to . . . 
bourgeois morality" (5). It is just such bourgeois morality-and its injurious effects upon poor African Americans-that comes under fire in Grimkés work.

Rachel acknowledges the vaunted promise of bourgeois class formationand then dashes it. In act 1, the Loving children are hopeful that a better life is on the horizon. Tom, exhilarated by the news that he has "made squad" at college, quips that he and Mrs. Loving will be forced to buy new hats because their heads are swelling from pride (16). The recognition of Tom's talents by his schoolmates enhances his mother's self-esteem and sense of well-being. "Ever since I told you," Tom teases, "you can almost look down your own back your head is so high" (16). His sister exhibits similar optimism. Rachel acknowledges that, while there is "no ... chance" that she will succeed in finding a position as a schoolteacher, her ongoing devotion to motherhood is compatible with the family's social aspirations (50). Rachel's desire for children is all consuming: "I just can't resist any child. I have to love it—it calls me-it-draws me" (12). Happily, the prospect of motherhood is near at hand. A courtship develops between Rachel and Mr. Strong, and Rachel soon finds herself "lost in a beautiful daydream" (52).

The ideals presented in the first two acts were emphasized in newspaper articles that both tracked and sought to shape black women's entry into the public sphere. Consider the representation of Mary Church Terrell, a board member of the Miner School and a well-known educator. In 1900 the Washington, DC, periodical The Colored American describes Terrell as the "premier representative" of modern black American womanhood and distinguishes her from the unflattering stereotype of a nineteenth-century women's movement activist. Unlike the "mannishly attired," "short skirted," and "short haired" women of the previous decade, Terrell exemplifies the "cultured, womanly woman" of the twentieth century. The periodical hails this new womanly ideal: "She is in many instances a mother, and she boasts of it and the home which she ennobles" ("Woman's Case" 1). Unlike earlier, ostensibly desexed generations of public women, Terrell signals the emergence of a quintessentially feminine model. Rachel's depiction of black ambition and aspiration acknowledges the salience of these ideals. Both aspects of Rachel's twofold dream - to be a teacher and a mother-are treated as closely aligned, if not interchangeable.

But Grimkés ultimate concern is critique. Rachel counters discourses that place conditions on black women's public participation in the struggle for political equality in two ways. First, and most obviously, it undermines popular maternalist ideology by calling attention to the legacies of slavery that continue to haunt black motherhood. In act 1, Mrs. Loving becomes conspicuously withdrawn as her daughter expresses her eagerness for motherhood and her inten- 
tion to spend her life protecting black children. The mother's wistfulness soon turns to pain. Her effort to restrain her daughter's maternal panegyrics- "Poor little girl!”-leaves Rachel perplexed (13). Such dreams, Mrs. Loving explains, will prove fruitless because of the extreme limitations placed on black women's ability to shield their children from harm. "I cannot save you," she concludes (13). Mrs. Loving's caution leads to the admission that she had been unable to save her husband and eldest son from a lynch mob, a revelation that triggers Rachel's descent into madness. In this way, dialogue between mother and daughter reveals that a cheerful embrace of maternal duty will safeguard neither black women's psychic health nor their claims to freedom. It is constructive, here, to recall Soyica Diggs Colbert's characterization of black drama as an act of history-making. "African American drama," Colbert writes, "returns to the scenes of crimes to interrupt historical processes used to render black people objects" (10). Mrs. Loving's intervention into her daughter's life represents an attempt to reconstitute maternal narratives through recourse to the lives and embodied stories of black women.

Second, the play draws attention to black women's restricted autonomy within the purportedly private sphere of the hetero-patriarchal family, thereby challenging a key principle of class-based racial uplift. Gaines writes: "What made uplift compelling for many African Americans was its vision of black freedom and security in the image of the home and patriarchal family" (7). Rachel's message - that marriage limits black women's freedom and is doomed to fail anyway-effectively shatters this vision. As his name implies, Mr. Strong is initially a harbinger of future happiness and a stalwart against the maelstrom of racist American society. But Strong is also sexually coercive. In act 2, Rachel complains that her lover's relentless attention is domineering. "Why, you talk as though my will counted for nothing," she says. "It's as if you're trying to master me" (51). Ultimately, though, the question of whether or not Rachel desires to take her place in Strong's 43rd Street apartment ("the prettiest, the most homelike little flat") is eclipsed by her sense that the promise of domestic security is hopeless (92). As Strong describes their future together, Rachel attempts to extract an impossible promise: that he will protect their future children and "keep away" the sound of their weeping (93). Rachel's double-pronged challenge to maternalism and patriarchy reveals the inadequacy of the bourgeois family as a vehicle for establishing or achieving freedom claims.

Grimkés play also spotlights the participation of both whites and black elites in the social and economic disenfranchisement of poor urban black people. In the context of the Miner School performance, such a critique would have been far more cutting than a simple critique of patriarchy. Despite Mrs. Loving's hope that moving her family out of the South would ensure a better 
life, the family is forced to acknowledge the realities of northern racism. In act 1, Rachel is pained to learn that her white friends have broken ties with the family because of racial prejudice. "They don't want you," Mrs. Loving explains; "they don't dare to like you" (20). The whole family is pained by this "lesson" (20). But Tom vocally expresses his indignation, pointing out that northern white hatred is the product of racism as it intersects with class-based economic chauvinism. While white people can expect success in the spheres of education, business, and politics, African Americans are "destined" to "grow up . . . in despair" (42). Moreover, Tom's recognition of the structural exclusion of black Americans leads him to critique the logic of cultural assimilation, declaring that he will eschew all social etiquette in his future dealings with whites. When Mrs. Loving protests that such behavior would not be "polite," Tom repulses her remonstrations: "If being a gentleman means not being a man-I don't wish to be one" (38). Tom's renunciation of bourgeois masculinity in this instance speaks to the conundrum faced by many African Americans attempting to carve out space for themselves within the American middle class. Social and economic status, as Lucy Moten found, exacted a price from black people who had to decide whether or not to accept the class-bound values of bourgeois privilege.

Even as the play confronts white racism, it is equally critical of intraracial class prejudice. While the Loving family is brought face-to-face with restrictions on their ability to secure work and enjoy a peaceful family life, Rachel's acquaintance with her new neighbor, Mrs. Lane, reveals the particular hardships suffered by the poorest African Americans, who find themselves excluded or directly targeted by both whites and relatively elite black people. Mrs. Lane, accompanied by her young daughter, Ethel, visits Rachel to inquire about the neighborhood and the local schools. Stage directions describe Mrs. Lane as "a black woman, poorly dressed," while Ethel is pictured as "a little, ugly black child" (52). The ensuing conversation between the two women speaks directly to the problem of color prejudice. Colorism in the United States, as Patricia Hill Collins argues, operates through the reproduction of "oppositional differences" between black and white (90). The depiction of the Lane family reveals that color hierarchies enact especially punishing exclusions and violence against dark-skinned African Americans. Mrs. Lane explains to Rachel that she has been forced to withdraw Ethel from school as a result of the brutal behavior displayed by teachers and pupils alike. Mrs. Lane condemns the treatment of Ethel, denouncing a world that victimizes her child "because God there made her ugly - and black" (56). Her anxiety about placing Ethel in a new school where there may be "brown" but not "black" children indicates that the child may have experienced bullying at the hands of both white children and 
lighter-skinned African American children (53). The play's focus on intraracial relationships in this instance calls attention to the urgency of re-forging the terms of racial uplift. Grimkés white allies may well have gained substantial insight from such representations. For an audience of black professionals, however, the play's critique of colorism may have presented an occasion for self-interrogation and, perhaps, contemplating the possibility of a different set of social practices.

Grimkés critiques of maternalism, professionalism, patriarchy, colorism, and education are withering. It is unsurprising that numerous scholars, from Tate onward, would read Rachel as a cry of despair. Indeed, at times the play cries out in just this way. And yet plays are also performed before audiences that might be by turns attentive and inattentive, rapt or dismissive. Plays offer their audiences a complex set of invitations that might be taken up, resisted, or reconfigured. As Fred Moten suggests, refusal and reproduction are coconstitutive elements of a work of art, and so no reading, however expansive or insightful, can settle meaning (5). The contingency of Rachel's critique is particularly salient, I suggest, because the play was staged before an audience that should have been resistant to its message. Through Lucy Moten's leadership, the Miner School came to represent nearly everything (professionalism, maternalism, and perhaps even patriarchal authority and colorism) that Rachel repudiated, yet Moten oversaw the play's production at the school, and the trainee teachers-upwardly mobile and professionalized surrogate mothers to black children-likely watched in the audience. It is to this history that I will turn next.

WATCHING RACHEL AT THE MYRTILLA MINER NORMAL SCHOOL

The Miner School production in March 1916 was Rachel's first staging, and although the play would be staged twice afterward, in Boston and New York, the Miner School production was a uniquely communitarian affair. The play was directed and performed by a local troupe of black actors, the Nathaniel Guy Family, and tickets were sold in a nearby drug store on the corner of 12th and U Streets, just a few blocks from the Miner School campus. Reading the play textually and in relation to biographical contexts, scholars following Tate have largely concluded that Rachel's cultural significance lies either in its crossracial appeal to white women on the grounds of shared commitments to antiviolence politics or in its significance as a forerunner to later artistic expressions of radical black protest. But narrowing our critical lens challenges these conclusions. If we pay attention to the local contexts surrounding the play's inaugural staging, we discover that Rachel is also about the struggles of black 
women to carve out viable avenues for personal and social visibility. Because the production was very much a community project, it is likely that it drew an audience from populations associated with the District of Columbia school system. With tickets selling for fifty and seventy-five cents, attendance would have been costly but not prohibitively expensive for the teachers and students at the school and their families. ${ }^{4}$ In this section I augment existing literary histories by examining the Miner School as an overlooked primary context for understanding Grimkés work. I also examine aspects of the play that directly intervene in the Miner School's educational discourses and institutional practices.

Around the time Rachel was performed at the Myrtilla Miner Normal School, Grimké was employed as a teacher at the Paul Laurence Dunbar High School in Washington, DC (Wilkinson 321). As a teacher, she likely had some understanding of the Miner School's culture and values when it hosted her play's premier staging on Friday, 3 March, and Saturday, 4 March 1916. The Miner School sought to produce a class of expert, professional, and dignified black women teachers. As head of the institution, Moten expected that all trainee teachers would acquire the intellectual skills necessary to teach in the city's elementary schools and newly established kindergartens. But she also required her charges to adopt the ways of cultured society. "True teachers," she asserted, understand the importance of "good behavior" and "refined manners" ("Normal School" 976). ${ }^{5}$ Following the debacle of her hiring, Moten likely had as good a sense as anyone of the risks awaiting those prospective teachers who failed to meet expectations. Whether or not she personally believed in social discipline, Moten promoted academic rigor and moral excellence. These traits, she claimed, would equip graduates to undertake the challenges and vicissitudes of service: "We want to meet all the demands of life ... . social, domestic, intellectual and professional" (qtd. in Corrothers 106). Moten's ambition remained constant over the course of her long career.

During these decades, black educators were at the forefront of a cultural and political battle to preserve and extend the rights of African Americans. Moten was not the only black woman leader to draw clear links between her social activism and her work as a teacher. Terrell, during her tenure on the Washington, DC, Board of Education, turned a public spotlight on new forms of dispossession affecting black people in the early twentieth century. In a 1904 article written for the North American Review, "Lynching from a Negro's Point of View," she criticizes what she sees as a racist double standard. First, white people deny African Americans education. Second, white people decry the uneducability of African Americans and point to their lack of formal education as justification for acts of political and physical violence. By calling attention to the structural forces contributing to the naturalization of white racist vio- 


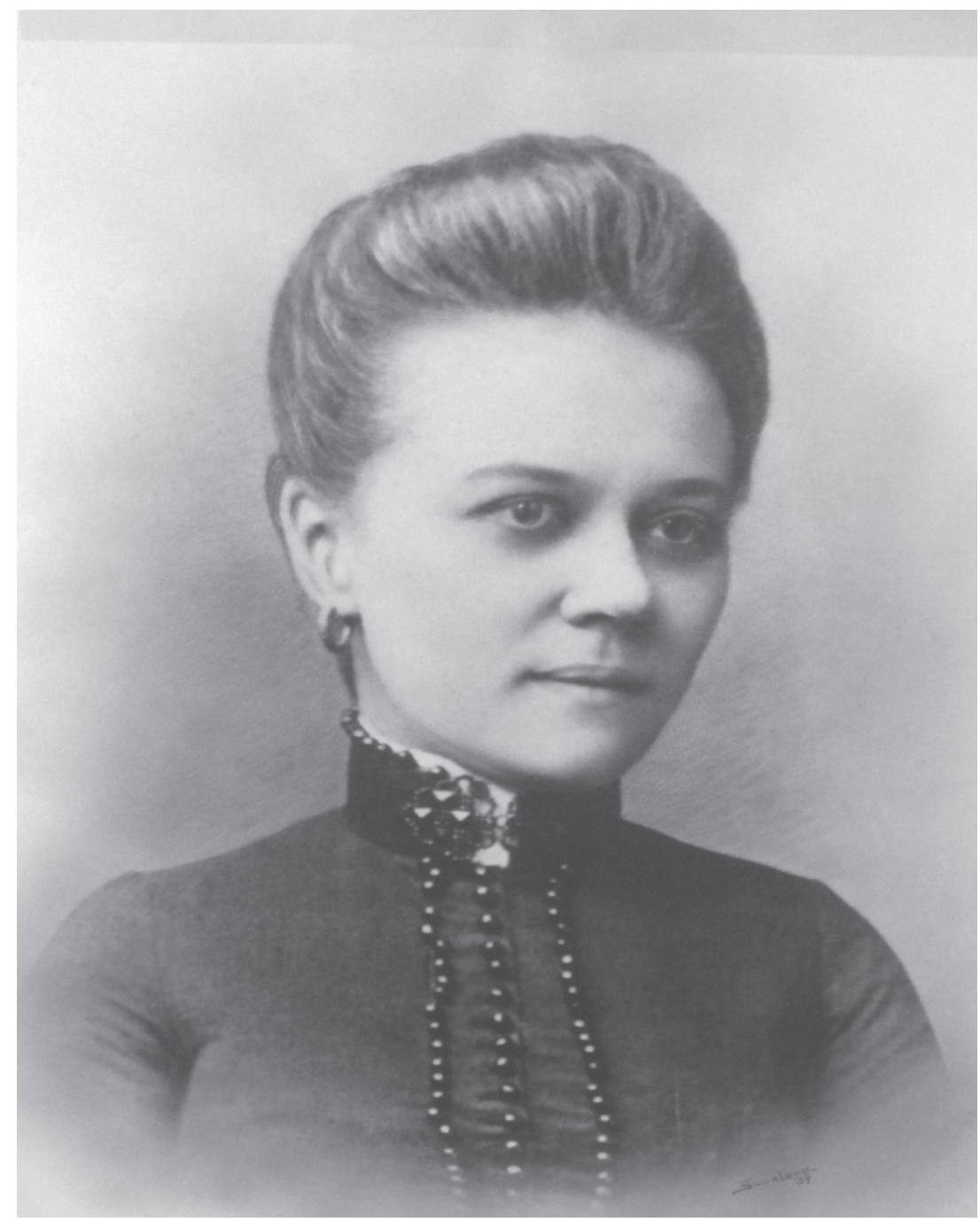

Fig. 1. Lucy E. Moten, c. 1876. University of the District of Columbia Archives.

lence, Terrell connects the federal government's failure to guarantee education for black children to the proliferation of racialized violence, writing that both situations are grounded in the same "spirit of vengeance and intolerance" (863). It would be difficult to overestimate the perceived importance of education as a strategy for protecting the well-being, even the lives, of black people.

Like Terrell, Moten devoted her life to overturning structural limitations 
placed on black freedom. At times, though, the principal doubled down on the politics of exclusionary bourgeois morality. Soon after her appointment, Moten recommended that the school's admissions policy be revised to bar prospective trainee teachers who did not convincingly demonstrate "general self-respect" (qtd. in Nelson 54). She also made entrance examinations more rigorous, a structural change that effectively cut annual admissions to the school in half. Moten defended her actions to the board by pointing out that this admissions policy "will give the Normal School your best material to prepare for teachers and enable us to protect the natural rights of the little ones entrusted to our care" (qtd. in Nelson 54). While Moten's disciplinary style consistently won her the approval of the school community, this same community was less impressed by policies they perceived as arbitrary and elitist. Admission to the school was one of the only routes by which young black women living in the Washington, DC, area could achieve professional employment and social standing. Members of the local community, including local newspaper editors, spoke out against the principal, arguing that her policies worked against the interests of the community as a whole (Nelson 54).

Black women teachers operated at the nexus of two distinct models of racial uplift. They were broadly committed to overturning racist social orders on behalf of all African Americans, and early commentators applauded their selflessness in "working for the race" (Majors 319). At the same time, these pioneering black professional women could not escape the fact that they lived and worked in a society that, in Gaines's words, "defin[ed] citizenship rights as a bourgeois privilege" (xx). Their sphere of action was perilous indeed. Scholars such as Tate and Mitchell have done much to illuminate Grimkés appeal to white audiences, but the fact that Rachel was initially performed at the Miner School begs the question of what this play may have meant to the black women who studied and worked at the institution, and who dreamed of a different life for themselves and their community.

In order to understand this meaning better, let us acknowledge that Grimkés denunciation of maternalism, professionalism, and uplift was scripted as a play designed to be performed publicly. This recognition should alert us to the important observation that a staged act of rejection is never a complete rejection. Black performance scholars have provided frameworks that bring theoretical weight to bear upon what I read as Grimkés critical negotiation with, rather than nullification of, narratives of respectable domesticity. Fred Moten's In the Break reveals the problem of taking at face value acts of nullification or rejection such as those displayed in Grimkés play. Such acts, Moten argues, in fact function within discourse. "A refusal of recitation," he 
writes, "reproduces what it refuses" (5). Black art, to the extent that it contests totalizing systems of presence and absence, constitutes a space of disruption and intervention.

It is just this kind of disturbance that would be visible in the Miner School performance of Grimkés play. Rachel summons discourses of the domestic and the maternal in order to push them away. This discursive gesture of repression abides within and reproduces the very values it claims to resist. In other words, the political efficacy of the play's conspicuous dis-identification with bourgeois respectability depends upon the abiding salience of this discourse within the aspirational culture of the black middle class. Fred Moten's articulation of black art as a space of disruption and invention, then, offers an inroad into understanding the play's discursive involvement with the culture of the Miner School. Just as the play constitutes a site of fraught dialogue about the continued relevance of black women's conventional roles and the project of bourgeois respectability, so, too, does the school. My analysis, then, draws attention to Rachel's disturbance of what might initially appear to be the school's established discursive frames. The play's rejection of domesticity, motherhood, and the efficacy of professionalism, I suggest, should be understood not as a rejection of uplift but rather, as part of the school's ongoing project of disruption and renegotiation of the terms of uplift.

Attending to the ways Rachel moves beyond the historical constraints imposed upon blackness enables us to see how the Miner School performance functioned as a site of disturbance or discursive instability. The play instantiates what Colbert refers to as the historical "excessiveness" of black drama (40). Colbert's study of black performance and theatrical reception, which incorporates and extends Fred Moten's concern with the "eventfulness" of black art, provides a vocabulary with which to articulate Rachel's critique of professional institutional practices (Colbert 13). "Black performance," Colbert writes, "intervenes in the past not to undo or override it but to actively engage and abide with it in the present" (11). Colbert suggests that black performance countenances and affirms the presentness of history and, in so doing, compels audiences to recognize and reflect upon their own ties to the past. Observed and criticized by white people and black men alike, the professional, respectable women at the school operated under conditions of intense scrutiny. Building upon Colbert's suggestion that black theater actively constitutes black audiences, I suggest that Rachel afforded the Miner School teachers an opportunity to reflect upon the routine challenges they confronted in their daily work (22). Women who had been made spectacles by virtue of their conspicuous social role became spectators themselves. They became the audience for a play that 
critiqued the very discourses of family formation, marriage, and child care that shaped their institutional mission.

Sitting in the audience, these women would have watched a play that turned a spotlight on the perils of black family formation. Moten, like many other latenineteenth- and early-twentieth-century black leaders, considered family stability the cornerstone of racial progress. Her teaching philosophy articulated her belief that black public school teachers were responsible for combating the effects of domestic disorder in the black community. "Sad but true," Moten writes, "very many of our children have not the refining influence of discipline at home." She continues:

Their families possess neither the virtue of a high standard of morality nor the softer amenities of that true refinement which takes its source in culture, hence they must grow up deficient in these essentials of a desirable character unless remedied by the example and teaching of the school-room. Let the teacher full of energy and enthusiasm, with a pure soul and elevated mind, and a refined manner, enter into this work, conscious of its great responsibility, with all her zeal, determined to counteract the evil influences on the outside, and appreciate her position for the grand opportunity it affords in preparing the young to become good and useful men and women. ("Normal School" 976)

Moten constructs the black household as a site in need of intervention, and the teacher as the agent of reform. Poor black families, she suggests, lack the intellectual motivation and moral determination to lift themselves out of poverty. In view of these circumstances, the teacher must shoulder the responsibility. Moten's class-based rhetoric was not uncommon among black leaders at the time. Black elites, Gaines observes, "seized upon the status of the family and moral and cultural distinctions . . . between themselves and the black masses to affi $\mathrm{rm}$ the class diff erences among African Americans that racist whites were loathe to acknowledge" (11). In other words, achieving class stratifi cation was proof of black progress. While Moten expresses regret that poor black families lack the resources to better themselves (such a state of aff airs is "sad"), her focus on institutional intervention eff ectively reproduces the social hierarchies that popular, collectivist discourses of uplift purported to combat. Moten, then, subscribed to a bourgeois understanding of uplift that served the interests of the black middle classes.

But it would be unfair-and inaccurate-to suggest that she simply ignored the plight of poor black families. Gaines argues that the behavioral patterns of black middle classes at this time too often matched those of mainstream whites. He states: 'African Americans' middle-class ideology, like the majority society's ideals of social mobility, remained trapped with that which it had denied, or 
tried to forget" (3). That Moten established moral boundaries between poor African American families and the "pure," "elevated," and "refined" young women at her school suggests that she fell into the kind of behavior Gaines describes (Moten, "Normal School" 976). But Moten also embraced a play that calls attention to the underlying structural factors that interfered with black family stability. With this in mind, I suggest Moten neither denied the plight of less fortunate African Americans nor tried to forget it.

Rachel addresses the divisive stereotypes about black families promulgated by the US mainstream only to collapse their underlying logic. In act 1, Tom raises the specter of black criminality through his account of the "Reynolds boy," a young, probably white man who is known by Tom's circle as the worst bully in the school (18). Tom explains the boy's behavior by pointing to the fact that his father is in prison. "No one likes him," Tom says, "[b]ut, then, what can you expect? His father's in 'quod' doing time for something” (18-19). Tom concludes his remarks with a word of sympathy for "decent" Mrs. Reynolds, who no longer mentions her husband's name (19). Mrs. Reynolds, Tom suggests, is right to be ashamed of her husband: "Bet I'd keep my head shut too;-you'd never get a yap out of me" (19). Tom's conversation provokes a visceral response from Mrs. Loving. She "stiffens" under her children's accusatory gaze, silently acknowledging their incorrect suspicion that Mr. Loving, like the disgraced Mr. Reynolds, is incarcerated (19). This uncomfortable exchange between mother and children prompts Mrs. Loving to set the record straight by telling them the truth about her husband's absence and the violence that wreaked havoc on their family years earlier. The suspicion of Mr. Loving's criminality gives way to an understanding of white criminal violence.

While the play's challenge to a white supremacist social order was in line with the activist work of Moten and Terrell, and while the appearance of a "race play" at the Miner School was not anomalous, the focus on marriage and motherhood would have been striking to those in the audience. While some black women professionals in Washington, DC, married, others refused the familial relations that the school sought to promote among the wider black community. Those who refused marriage had good reason to do so. The trappings of ideal domesticity-marriage and motherhood-threatened black women's ability to participate fully in a highly competitive professional field. Anna Julia Cooper, principal of the M Street High School (renamed Paul Laurence Dunbar High School in 1916) in Washington, DC, acknowledged the specific challenges of black women when she suggested that they are "confronted by both a woman question and a race problem" (Voice 134). As a teacher and (following the death of her husband) a single head of household, Cooper was keenly aware of the race- and gender-specific economic burdens 
that restricted African American women. ${ }^{6}$ In her writing about women's labor, Cooper defends black women's right to wage-earning labor via "the broadest and fullest development of . . p powers," even while acknowledging that their participation in waged work must inevitably compromise their role as domestic helpmeets ("Colored Women" 296). Becoming a wife and mother, in short, threatened to close the only gateway to a new world of social and professional esteem, and, for some women, the chance to survive economically.

Social, professional, and economic pressures to remain single were compounded by institutional regulations that discouraged trainee teachers from pursuing marriage and motherhood. After 1887, trainees admitted to the Miner School were required to pledge that they would devote themselves solely to their training and, later, to the work of teaching for a period of at least two years. Such frameworks were designed to preclude a change in profession or marriage for the duration of a teacher's early career. This pledge remained a requirement for almost thirty-five years, until it was repealed in 1921 (Nelson 58).

Moten's own decision not to marry was perhaps influenced by such considerations. Certainly, her choice was not uncommon among turn-of-thecentury professional women. During this period, when women were entering into the higher professional echelons in significant numbers for the first time, many resisted the pressure to marry in order to better fulfill their ambitions. As Lillian Faderman observes, the possibility of combining marriage and career was not widely modeled. "It must have seemed to many of these pioneering women," Faderman writes, "that a renunciation of marriage was demanded of them no less than it was of a nun" (17). It is possible, then, that Moten saw marriage as a distraction, a threat to her professional career, or both. Of course, this is not the only possible explanation. Faderman also notes that women's choice not to marry sometimes "served as an excuse to remain heterosexually celibate" (17). Moreover, it is certainly not out of the question that Moten chose not to marry because she was intimately involved with another woman. Spare hints of Moten's relationship with Caroline E. Parke, another teacher in the Washington, DC, school system, can be found in letters written by friends detailing Moten's life and family relations. Moten and Parke "went to school hand-in-hand" before pursuing careers as teachers in the city, and Parke was known to acquaintances as the principal's "life-long friend" (Corrothers 102). Regardless of the underlying reasons, it is clear that the principal-and likely her staff, too-did not practice the stable conjugal partnerships they promoted among members of their community.

Like the teachers at the school, Rachel is forced to acknowledge marriage and motherhood as fraught and potentially disabling. Though she does not 
reject her lover's proposal explicitly, her refusal is strongly implied at the end of the play when she destroys Strong's bouquet of roses, which symbolize Rachel's longing for children:

You can laugh, O God! Well, so can I. (Bursts into terrible, racking laughter) But I can be kinder than You. (Fiercely she snatches the rosebuds from the vase, grasps them roughly, tears each head from the stem, and grinds it under her feet. The vase goes over with a crash; the water drips unheeded over the tablecloth and floor.) If I kill, You Mighty God, I kill at once-I do not torture. (63)

Reading the play textually, one might be compelled to ask why the violent dismemberment of flowers constitutes the climax of an anti-lynching problem play. Indeed, scholars have addressed this question. Mitchell observes that such striking scenes convey the impact of lynching on the living. "Wrongful death," she writes, "does not simply destroy an existing household; it prevents the creation of new ones" (56). Rachel's destruction of the flowers, Mitchell suggests, registers the "generational consequences" of racialized violence and the nation's failure to hold white racists to account for their crimes (56).

But reading the play through the context of the Miner School offers additional insight into the historical significance of such scenes. The Miner School teachers were tasked with transmitting conjugal values in their everyday work, and it is by no means unlikely that at least some desired marriage and children for themselves. But they faced hard choices. They might devote themselves to marriage and the reproduction of the black family or they might pursue their careers and, in doing so, compromise tenets of racial uplift that sought to construct black women as private, protected subjects. Both of these options were burdened by the weight of history, and neither path was guaranteed to yield happiness, social standing, or security. Rachel's impulsive and violent actions, then, further disrupt the very modes of conventional femininity that were already radically unstable for the Miner School teachers. The stage directions maximize dramatic effect. The livid-indeed, frenzied-dismembering of the roses visualizes a stark rejection of the conventions of domesticity they represent. Whereas Rachel's ethical determination-that it would be right to kill black children rather than allow them to be lynched-remains a fantasy, the destruction of the flowers represents a bid for agency within the narrow parameters of her sphere of action and influence. Rachel's staged rejection of marriage and motherhood is a remarkably fitting testament to the complicated domestic arrangements of the teachers at the school.

Even as they faced difficult choices regarding marriage and motherhood for themselves, the Miner School teachers performed the role of professionalized caretakers for the city's children. Moten was a keen advocate of "child 
study," an early version of what educators today might refer to as the science of early childhood development. "If there is to be any advancement in our children by and through educational methods," Moten writes as early as 1896, "it must lie in the direction of the children themselves." As is the case today, practitioners of child study at the turn of the century sought to understand how environmental factors shape children's moral, intellectual, and emotional development. Trainee teachers at the Miner School were expected to perform a "systematic study" of individual children. They recorded the child's conduct, manners, and intellectual standing over a period of time and sought to uncover the cultural and environmental determinants affecting the child's personality. The trainees presented their findings to the principal in the form of monthly reports (Moten, "Child Study" 193). Evidently, the trainee teachers were expected to devote tremendous amounts of time and energy to the study of each child's development. Rachel's cry of hopelessness would perhaps have been resonant, but it would have represented a repudiation of the underlying ideology of child study.

This focus on early childhood study at the Miner School was augmented by the school's involvement with community development projects and events. In April 1915 the school hosted a musical involving some fifteen hundred black schoolchildren. Also, in the weeks prior to Rachel's production in November 1916 the school put on an exhibition of artwork produced by young children of the city, showcasing for the community the children's acquired skills and creativity. ${ }^{8}$ These events reaffirmed the institution's commitment to children. Displays of musical proficiency and artistic talent publicly testified to Moten's success in cultivating ability and propagating refinement and taste among the city's young people. The Miner School educators self-consciously constructed the school as a site of black performance. In doing so, they cultivated art that affirmed black children's - and by extension black people's - capacity for intellectual and creative self-definition.

Given the school's interest in child study as pedagogical theory and practice, it is not difficult to see why Moten and her trainee students might have been attracted to a play that focuses on the physical and psychological impact of racialized violence on black children. Rachel, as I discuss above, highlights the pain suffered by black children who are ridiculed and excluded by their peers. But Mrs. Lane's account of her daughter's suffering also speaks specifically to the harm caused by inattentive and cruel teachers. Ethel's teacher subjects her to humiliation by ignoring her presence in the classroom and then punishing her for "sulkiness" by detaining her during recess (56). The depiction of Ethel's alienation-she sits alone in silence while the other children happily play in the school yard-reinforces Tom's earlier observation that African Americans are 
"destined" to be deprived of the privileges enjoyed by whites (42). Mrs. Lane's account culminates by detailing the teacher's complicity with the children's racist bullying. The teacher tells the children that their name-calling "isn't nice," but her conspiratorial smile indicates that she ultimately sides with the bullies (57).

Rachel's representation of poor black children may have invoked a number of responses from its early audience. Given the ideological commitments of the school, however, it is likely that such scenes were met with profound sympathy. Though Mrs. Lane does not specify the race of the teacher who torments Ethel, the audience could infer that she was white. For any young trainee teachers in the audience, the play's depiction of a teacher's racist domination of a vulnerable child perhaps served to reinforce a sense of mission, reminding them that their service to the community was needed and valued. If this were the case, the play may have effectively bolstered what Gaines describes as the "popular social image" of racial uplift (xv). Rachel brings the psychic, physical, and emotional pain of poor black children into the school and, in so doing, reasserts the need for group struggle. In this way, the play functions as anti-racist propaganda and is in line with the traditional objectives of the school as a site of racial uplift.

But as well as confirming the school's ideological mission, the play may have awakened critical self-reflection and even self-doubt. Certainly, Rachel's depictions of childhood suffering call attention to the need for continued anti-racist struggle, but the overall message of the play is that current strategies are not working. Mrs. Lane's lament to Rachel at the end of their visit directly articulates this message: "Every year things are getting worse" (57). Mrs. Lane follows up this cry with a rhetorical question that cuts through the institutional rhetoric: "[I]t's all rather useless-this education! What are our children going to do with it, when they get it? We strive and save and sacrifice to educate them-and the whole time-down underneath, we know-they'll have no chance" (58). Despite decades of struggle, black freedom remains a distant goal. Mrs. Lane's cry must have been disturbing for the Miner teachers, who devoted their lives to education. Just as the women at the Miner school could hardly have failed to recognize the stakes of the Lovings' daydreams about professional and domestic fulfillment, neither could they have failed to feel the weight of this accusation of deficiency.

Rachel's place in the performance repertoire of the Miner School reveals that the play's refusal of the bourgeois ideal was a constitutive element of bourgeois morality as it operated at the institution. If, as Colbert suggests, black drama is "excessive," then we need not attempt to settle its contradictions (96). And if, as Fred Moten suggests, black performance "reproduces what it refuses," then the play can function as a critique of uplift while nonetheless abiding within the spaces of that uplift's production (5). For Tate, Rachel's denunciation of domes- 
tic ideals is symptomatic of an already existing and widespread culture of disillusionment among African Americans in the early twentieth century. And yet, by taking into consideration the specific location in which the play was performed we can see that Rachel brings histories of black maternal violence and intraracial class conflict into a school environment devoted to promoting the same bourgeois ideals - maternalism, family formation - that Tate suggests were becoming obsolete among the broader population. I suggest that the easy dichotomy between the discourses of the aspirational black middle class and the discourses of despair need not be conceptualized as a dichotomy at all. Rather, Rachel reveals the inter-animating relation between the bourgeois and the radical, the maternal and the refusal of maternity.

\section{PROFESSIONALISM, PERFORMANCE, POLITICS}

Over the last three decades, scholars have consistently looked to historical context in order to assess the aesthetic and cultural significance of Grimkés work. Collectively, they have provided an account of the play that takes into consideration the author's biographical influences, her location within a community of progressive black activist intellectuals, and her position in relation to earlier black women writers. Such recovery is a welcome development. The inclusion of Rachel in an edited collection of anti-violence protest plays by American women writers will doubtless ensure that the play continues to find new readers and audiences (Perkins and Stephens 23-78). And yet there is still work left to do if we are to fully realize the significance of the intersection between literary and extra-literary archives.

I suggest throughout this essay that performance offers a set of invitations that audience members might take or resist, consider or dismiss. Considered in this way, the reactions of the Miner School audience are unknowable. Did they think of their own pupils when they heard of Ethel's struggle at school? Did they agree with Mrs. Lane that "every year things are getting worse" (57)? Reactions likely varied. And yet, examining Rachel in relation to the community within which it was first produced offers substantive context for theorizing the significance of the play's appeal to black audiences. While scholars of the play, from Hull and Tate onward, contend that Rachel can best be read as an appeal to white allies, my analysis reveals that such conclusions fail to grapple with the fact that African American women enabled the inaugural production and then participated as audience members. My account of this participation suggests that even while they recognized the political expediency of bourgeois respectability discourses, early- twentieth- century black women professionals 
involved themselves in the intellectual work of critiquing and rethinking the meaning of those discourses, for both themselves and others. Their work, in short, was intellectually generative.

Ultimately, my account of the play as a school project offers more-nuanced insight into how black women negotiated complicated political challenges in these decades. When Rachel was brought into the Myrtilla Miner Normal School in March 1916, it was met by professional black women committed to racial equality. These teachers also worked to achieve social recognition for themselves as African American women specifically. Even as they sought radically new expressions of black womanhood, they were hemmed in by racist and patriarchal structures that placed limitations on their professional and sexual freedoms. Hyperawareness about the domestic legacies of slavery, particularly the sustained attack on black women's status as mothers, produced anxieties among black intellectuals about women's work outside the home. Partly for this reason, professionalism and maternalism became closely related-at times indivisible-preconditions of black women's participation in civic society. In this respect, the Miner School teachers were professionals par excellence, as a 1917 report in NAACP organ The Crisis confirms: "The institution [the Miner School] is contributing powerfully to the efficiency of family and school life, not only in the District of Columbia, but in many parts of the United States" (Jenifer 281). And yet, tracing Moten's complicated relationship with bourgeois respectability provides an intimate picture of the intense political conditioning of women in the vanguard of the burgeoning black professional class, and offers insight into their capacity for self-critique.

We are left, then, with a complex picture of professional black women's role as arbiters of middle-class privilege. On the one hand, Moten reproduced the values that had initially threatened to block her entry into the higher echelons of the Washington, DC, educational system. She went above and beyond professional expectations when she argued in favor of narrowing opportunities for other black women. On the other hand, Moten invited radical critique into her school, indicating that her views on uplift were far from settled. Through a threefold critique - of family formation, marriage, and childhood sufferingRachel directly concerns the growing divisions between relatively elite and non-elite black people and the broken promise of black education. The fact that the school provided a venue for this play suggests that those working within the institution were, at the very least, receptive to criticisms of the ideological frameworks they were engaged in producing. 
Many thanks to the Legacy readers and editors for their insightful comments and suggestions. Thanks also to Chris Anglim, who directed me to the Nelson institutional history and tracked down other archival materials, and to Shawn Salvant, who provided valuable feedback on an early draft of this essay.

\section{NOTES}

1. Moten's middle name appears as "Ellen" in some places, including Corrothers's biographical essay and the Washington, DC, elementary school named after her.

2. The Myrtilla Miner School was in earlier years known as the Washington Normal School. For a general institutional history of the school, see Nelson; and Null 254-68.

3. My discussion of this incident is based on Corrothers 103 .

4. In 1915, schoolteachers in the District of Columbia could expect to receive a salary between $\$ 600$ and $\$ 1,200$, depending upon the school and their rank. Wages for schoolteachers in the District were below the national average. For salaries, see Report of the Board of Education, 1911, 33, and Annual Report of the Commissioners, 1915, 73.

5. Members of the Washington, DC, community spoke of the institution as a finishing school; see Nelson 49.

6. For discussion of Cooper's career challenges, see May 16-20.

7. For a discussion of Moten's relationship with Parke, see Corrothers 102. Parke's name appears among the lists of teachers working in the Washington, DC, school system. For example, see District of Columbia Board of Commissioners, “Teachers, Residences, Salaries, \&C” 201.

8. On 26 November 1916 the Miner School exhibited displays made by young Washington, DC, children at school playgrounds over the summer. A timeline of events was provided for me by reference librarian and archivist Christopher Anglim at the Learning Resources Division, University of the District of Columbia.

\section{WORKS CITED}

Anglim, Christopher. Personal email correspondence. 8 Sept. 2014.

Colbert, Soyica Diggs. The African American Theatrical Body: Reception, Performance, and the Stage. Cambridge UP, 2011.

Collins, Patricia Hill. Black Feminist Thought: Knowledge, Consciousness, and the Politics of Empowerment. Routledge, 2002.

Cooper, Anna Julia. "Colored Women as Wage Earners." Southern Workman, vol. 28, no. 1, Aug. 1899, pp. 295-98. 
. A Voice from the South. 1892. Oxford UP, 1988. The Schomburg Library of Nineteenth-Century Black Women Writers.

Cooper, Brittney C. Beyond Respectability: The Intellectual Thought of Race Women. U of Illinois P, 2017.

Corrothers, Thomasine. "Lucy Ellen Moten, 1851-1933." Journal of Negro History, vol. 19, no. 1, Jan. 1934, pp. 102-6.

District of Columbia Board of Commissioners. Annual Report of the Commissioners of the District of Columbia Year Ended June 30, 1915. Vol. IV: Report of the Board of Education. Washington, DC, Government Printing Office, 1915. Google Books.

- Report of the Board of Education to the Commissioners of the District of Columbia, 1908-9. Washington, DC, Government Printing Office, 1911. Google Books.

—. "Teachers, Residences, Salaries, \&C." Sixth Report of the Board of Trustees of Public Schools of the District of Columbia, 1879-'8o. Washington, DC, Globe Printing and Publishing House, 1881, p. 201. Google Books.

Faderman, Lillian. Odd Girls and Twilight Lovers: A History of Lesbian Life in Twentieth-Century America. 1991. Columbia UP, 2012.

Gaines, Kevin K. Uplifting the Race: Black Leadership, Politics, and Culture in the Twentieth Century. UNC P, 2012.

Gourdine, Angeletta K. M. “The Drama of Lynching in Two Blackwomen's Drama, or Relating Grimke's Rachel to Hansberry's A Raisin in the Sun." Modern Drama, vol. 41, no. 4, 1998, pp. 533-45.

Grimké, Angelina Weld. Rachel. Cornhill Company, 1920.

Higginbotham, Evelyn Brooks. Righteous Discontent: The Women's Movement in the Black Baptist Church, 1880-1920. Harvard UP, 1993.

Hull, [Akasha] Gloria T. Color, Sex \& Poetry: Three Women Writers of the Harlem Renaissance. Indiana UP, 1987.

Jenifer, George D. “The Myrtilla Miner Normal School.” Crisis, vol. 13, no. 6, Apr. 1917, pp. $278-81$.

Majors, Monroe Alphus. Noted Negro Women: Their Triumphs and Activities. Chicago, Donahue and Henneberry, 1893.

May, Vivian M. Anna Julia Cooper, Visionary Black Feminist: A Critical Introduction. Routledge, 2007.

Mitchell, Koritha. Living with Lynching: African American Lynching Plays, Performance, and Citizenship, 1890-1930. U of Illinois P, 2011.

Moten, Fred. In the Break: The Aesthetics of the Black Radical Tradition. U of Minnesota P, 2003.

Moten, L. E. [Lucy Ella]. "Child Study." Report of the Board of Trustees of Public Schools of the District of Columbia to the Commissioners of the District of Columbia, 
1894-95. Washington, DC, Government Printing Office, 1896, pp. 193-94. Google Books.

. "Normal School." Annual Report of the Commissioners of the District of Columbia for the Year Ended June 30, 1889. Washington, DC, Government Printing Office, 1889, pp. 974-79. Google Books.

_. "Report of the Principal of Myrtilla Miner Normal School." Annual Report of the Commissioners of the District of Columbia Year Ended June 30, 1918. Vol. IV: Report of the Board of Education, 1917-1918. Washington, DC, Government Printing Office, 1918, pp. 317-20. Google Books.

Nelson, Bernard H. "Miner Teachers College: The First Century 1851-1951: The Biography of a School." Washington, DC, published by Nelson, 1973.

Null, Druscilla J. "Myrtilla Miner's 'School for Colored Girls': A Mirror on Antebellum Washington." Records of the Columbia Historical Society, Washington, DC, vol. 52, 1989, pp. 254-68.

Perkins, Kathy A., and Judith Louise Stephens, editors. Strange Fruit: Plays on Lynching by American Women. Indiana UP, 1998.

Stephens, Judith L. "The Anti-Lynch Play: Toward an Interracial Feminist Dialogue in Theatre." Journal of American Drama and Theatre, vol. 2, no. 3, 1990, pp. 59-69.

Tate, Claudia. Domestic Allegories of Political Desire: The Black Heroine's Text at the Turn of the Century. Oxford UP, 1992.

Terrell, Mary Church. "Lynching from a Negro's Point of View." North American Review, vol. 178, no. 57, 1904, pp. 853-68.

Wilkinson, G. C. "Report of the Principal of Dunbar High School." Annual Report of the Commissioners of the District of Columbia Year Ended June 30, 1918. Vol. IV: Report of the Board of Education, 1917-1918. Washington, DC, Government Printing Office, 1918, pp. 320-24. Google Books.

"Woman's Case in Equity." Colored American, vol. 7, no. 47, 17 Feb. 1900, pp. 1 \& 4. 